\title{
Stabilization of Organic Matter in the Raised-Bed Soils of Tidal Swamplands is Influenced by The Types and The Amounts of Organic Matter Application
}

\author{
A.R. SAIDY ${ }^{1}$, I. KHAIRULLAH ${ }^{2}$, M. SEPTIANA ${ }^{\mathbf{1}}$, AND E. TRIATMOKO ${ }^{\mathbf{3}}$ \\ ${ }^{1}$ Department of Soil, Faculty of Agriculture, LambungMangkurat University, Banjarbaru \\ ${ }^{2}$ Swampland Agriculture Research Institute, Jalan Kebun Karet, Banjarbaru,South Kalimantan \\ ${ }^{3}$ Facultyof Agriculture, Achmad Yani University, Banjarbaru,South Kalimantan
}

\begin{abstract}
Farmers in tidal swamplands annually added organic matter (OM) onto the raised beds to maintain organic matter contents and thereby maintain soil productivity of the raised beds. This experiment aimed to study the influence of the types and the amounts of OM on the stabilization of organic matter in the raised-bed soils. Four types of OM: rice straw, eceng gondok (Eichornia crassipes), purun tikus (Eleocharis dulcis) and mixed rice straw-eceng gondok were added to a 27-year raised bed soil with 4 different rates: $0,0.5,1.0$ and 2.0 of maximum sorption capacity $\left(\mathrm{Q}_{\max }\right)$, and the $\mathrm{OM}$ stabilization was quantified after 10 weeks of $\mathrm{OM}$ addition. Results of this study showed with the exception of rice straw, OM addition to soil resulted in increases in the mineralization of soil OM thereby inducing priming effect. Addition of rice straw at rate of 0.5 of $\mathrm{Q}_{\max }$ resulted in stabilization of $46 \%$ added $\mathrm{OM}$, while only $30 \%$ and $37 \%$ of added $\mathrm{OM}$ was stabilized when $\mathrm{OM}$ was added to soils at rates of 1.0 and $2.0 \mathrm{Q}_{\max }$, respectively. This study showed that the stabilization of OM in raised bed soils were influenced by the chemical composition of OM and the amount of added OM.
\end{abstract}

Key-words: adsorption, green-house gas emission, carbon retention, ligand exchange

\section{INTRODUCTION}

Farmers of tidal swamplands generally halved their land; some areas of the land were left in flooded condition and planted with rice, while other part of the land were elevated through the deposition of muddy siltclay minerals from surrounding areas. In the raised-beds, the farmers then cultivated crops, cassava, fruits and perennial crops. Crop productivity in the raised beds varies with the age raised beds. Reduction in the crop productivity may due to changing organic matter contents in the raised-beds with increasing the age of raised-beds. Study conducted by Rasmadi (2003) showed that the

Correspondence: A.R. Saidy, Department of Soil, Faculty of Agriculture, Lambung Mangkurat University, Banjarbaru 70714, Indonesia. Phone: +62 511 4777540, fax: +62 5114772254 ,

email: asaidy@unlam.ac.id content of organic carbon and nitrogen decreased with progressing the age of raisedbeds.

Farmers annually deposed organic matter that has decayed and mixed with muddy siltclay minerals from sunken-beds and then piled them onto the raised-bed. The purpose of mixed silt-clay-OM deposition onto the raised-bed is to elevate raised-bed surface. This process may also improve the stabilization of organic matter through the interaction between iron and aluminium oxides that may be contained in the silt-clay minerals and organic carbon present in soils.

Stabilization of $\mathrm{OM}$ in soils is controlled by several factors: chemical composition of OM, presence of soil minerals such as phyllosilicate clays and oxide and the accessibility of microorganisms for $\mathrm{OM}$ in soils (Baldock et al., 2004; Saidy et al., 2012a; 2013b). Lignin,with its aromatic ring structures, is recognised to be more resistant to decomposition than carbohydrates, and together with alkyl carbon areconsidered to account for a biochemically stable component 
of SOC (von Lützow et al., 2006). However, information on the stabilization of $\mathrm{OM}$ in the raised bed soils with different types of $\mathrm{OM}$ is not available. The objective of this study was to quantify the effect of types and the amount of OM addition on the amount of OM stabilized in the raised-bed soils through incubation study in the laboratory.

\section{METHODS}

Soils used for the study were sampled from the Village of Karang Indah, Mandastana District, Kuala Barito Regency, South Kalimantan Province. A-raised-bed experiencing 27 years (made in 1987) has been selected for this study based on the results of interviews with farmers and field surveys.Soil samples were collected from a depth of $0-30 \mathrm{~cm}$ at several different points. Once cleaned for plant debris, soil samples were then homogenized, stored in plastic bags and stored at $4^{\circ} \mathrm{C}$. Samples were then airdried for incubation experiment.

Four types of OM: rice straw, eceng gondok (Eichornia crassipes), purun tikus (Eleocharis dulcis) and mixed rice straweceng gondok were collected from same area of soil sampling. All OM were oven-dried at $50{ }^{\circ} \mathrm{C}$ and then ground to $<2 \mathrm{~mm}$. Chemical analyses were conducted for all $\mathrm{OM}$ to determine contents of organic $\mathrm{C}$, total $\mathrm{N}$, hot water soluble $\mathrm{C}$, cellulose, hemicellulose and lignin (Bremer and Malvaney, 1982; Chesson, 1991; Nelson dan Sommers, 1996). The chemical composition of OM used in this study is described in Table 1.

Table 1. Chemical composition of organic matter

\begin{tabular}{lcccc}
\hline \multicolumn{1}{c}{ Characteristics } & Rice straw & $\begin{array}{c}\text { Eceng } \\
\text { gondok }\end{array}$ & Purun tikus & $\begin{array}{c}\text { Mixed rice } \\
\text { straw-eceng } \\
\text { gondok }\end{array}$ \\
\hline 1. Organic $\mathrm{C}\left(\mathrm{g} \mathrm{kg}^{-1}\right)$ & 369.7 & 298.7 & 320.8 & 304.5 \\
2. Total nitrogen $\left(\mathrm{g} \mathrm{kg}^{-1}\right)$ & 16.8 & 20.5 & 18.6 & 17.9 \\
3. Hot water soluble C $\left(\mathrm{g} \mathrm{kg}^{-1}\right)$ & 17.5 & 24.5 & 19.3 & 17.4 \\
4. Cellulose $\left(\mathrm{g} \mathrm{kg}^{-1}\right)$ & 29.3 & 36.5 & 34.2 & 31.3 \\
5. Hemicellulose $\left(\mathrm{g} \mathrm{kg}^{-1}\right)$ & 25.4 & 21.3 & 29.5 & 33.5 \\
6. Lignin $\left(\mathrm{g} \mathrm{kg}^{-1}\right)$ & 25.7 & 16.1 & 14.9 & 16.7 \\
\hline
\end{tabular}

Air dried-raised bed soils were mixed homogenously with each OM (for each treatment) in the PVC tube (radius $1.95 \mathrm{~cm}$ ). The mixtures were then compacted to a give a depth of $2.0 \mathrm{~cm}$ to obtain a bulk density (BD) of compacted soils similar to the BD measured in the field. Distilled water was then added to obtain $70 \%$ water-filled pore space (WFPS). The PVC tubes were then transferred into $1 \mathrm{~L}$ Mason jars containing 5 $\mathrm{mL}$ deionised water in a $20 \mathrm{~mL}$ plastic vial to maintain humidity. The jars were sealed with air-tight lids with rubber septa to allow sampling of gas from the jars and incubated in the dark at room temperature for 10 weeks. For each treatment, three replicate samples were prepared and incubated. Organic C stabilization was measured by determining the headspace $\mathrm{CO}_{2}$ concentrations within each jar, using a Servomex 1450 infra-red gas analyser (Servomex, UK). Carbon dioxide was measured repeatedly for each sample over the duration of the experiment.

Analysis of variance was performed on the data of $\mathrm{C}$ mineralization to quantify the effect the types and the amounts OM addition on OM stabilization. All statistical analyses were performed using GENSTAT $12^{\text {th }}$ Edition (Payne, 2008). 


\section{RESULTS AND DISCUSSION}

Analysis of variance revealed that the types and the amount of OM added to soils influenced significantly OM stabilization. Based the types of OM, carbon mineralization increased in the order of rice straw $<$ mixed rice straw-eceng gondok < eceng gondok < purun tikus (Fig. 1). The lowest carbon mineralization was observed with rice straw application was attributed to the fact that rice straw had the highest lignin content compared to other OM (Table 1). Effect of lignin content on $\mathrm{OM}$ decomposition were also reported by Yuwono (2008) and Aprianis (2011) who found an inverse relationship between lignin content and decomposition rate of $\mathrm{OM}$.

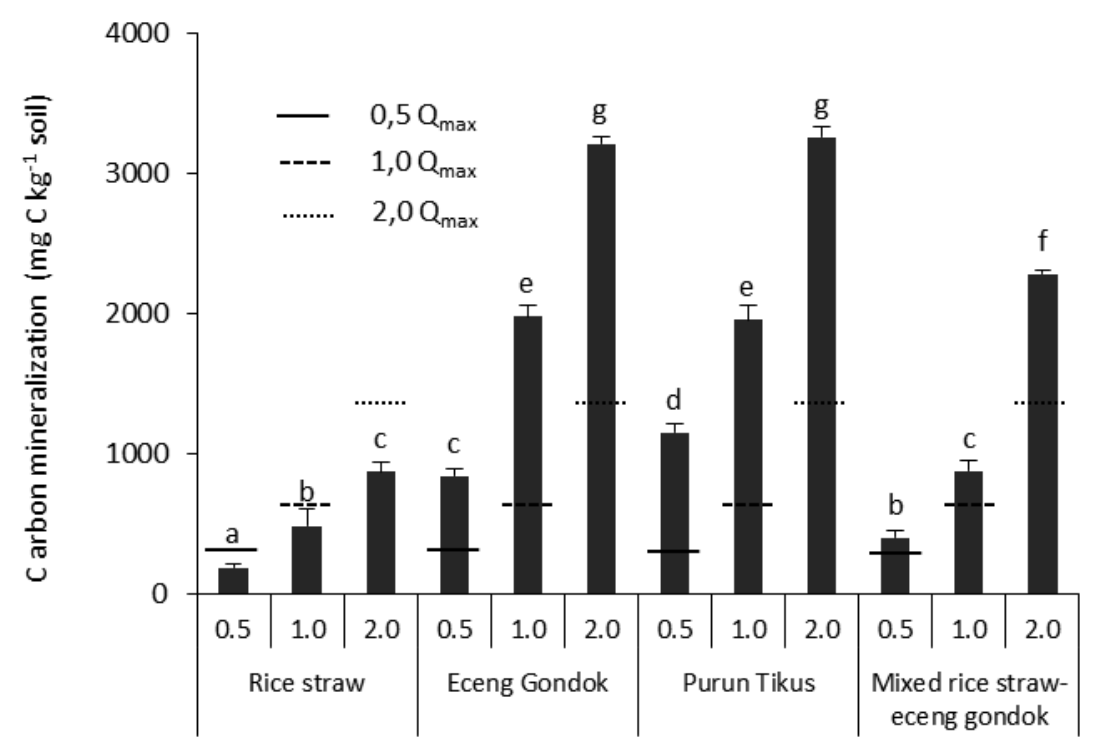

Fig.1.Carbon mineralization of OM applied to the raised-bed soil with different types and amount after reduced by carbon mineralization from soils. The line above the bars are the standard deviation of the mean $(n=3)$. The same letters above the bars indicate the treatment effect is not different based on the Duncan's Multiple Range Test (DMRT ) at 5\%. Notation of $0.5 \mathrm{Q}_{\max }, 1.0 \mathrm{Q}_{\max }$ and 2.0 $\mathrm{Q}_{\max }$ indicates the amount of OM applied to soils is equivalent to $0.5,1.0$, and 2.0 times the soil maximum capacity soil to adsorb OM.

To determine the amount of carbon mineralized only from OM, carbon mineralized from the soil and OM is reduced by the amount of carbon mineralized only from thesoils (Fig.1). Fig.1 shows that with the exception of rice straw, the amount of carbon mineralization of OM after deducting the carbon mineralization of the soil is higher than the amount of carbon added to the soils. This was observed at all levels of the addition of organic matter (Fig. 1). The higher carbon mineralization of eceng gondok, purun tikus, and mixed rice straw and eceng gondok was attributed to the mineralization of organic carbon present in raised-bed soils after the addition of $\mathrm{OM}$ to soils. Mineralization of natural $\mathrm{OM}$ in soils due to the addition of fresh or new $\mathrm{OM}$ is known as priming effect (Fontaine et al., 2004; Fontaine et al., 2007). The addition of fresh OM will activate soil microorganisms that were previously dormant, which in turn improve the processes mediated by microorganisms such as the decomposition of natural organic matter (Blagodatskaya and Kuzyakov, 2008). Therefore, the addition of eceng gondok, purun tikus and mixed rice straw-eceng gondok will reduce the content of $\mathrm{OM}$ in the raised-bed soils, while rice straw addition 
resulted in an improvement of OM content in the raised-bed soils through OM stabilization. Fig. 1 also shows that $54 \%$ of the OM added to the soilswas decomposed and returned to the atmosphere as $\mathrm{CO}_{2}$ at level addition of 0.5 $\mathrm{Q}_{\max }$. A portion of added OM that does not decompose (46\% of rice straw added to soil) was stabilized at raised-bed soils which in turn will increase the OM content of soils. At the level of the addition of OM 1.0 and 2.0 $\mathrm{Q}_{\max }$, only $30 \%$ and $37 \%$ of rice straw added to the soilswas stabilized by mineral soils, respectively. Thus, the amount of rice straw to be applied to the raised-bed soil to generate increased soil $\mathrm{OM}$ is equivalent to $0.5 \mathrm{Q}_{\max }$ (half of the maximum capacity of the soil adsorb OM).

\section{CONCLUSION}

Results obtained in this study revealed that among types of OM (rice straw, eceng gondok, purun tikus, and mixed rice straweceng gondok) were applied to the raised bed soils, rice straw produces the highest stabilization of OM. The stabilization of rice straw was related to the chemical composition of rice straw containing compounds are relatively difficult to be decomposed. Results of the study also show that the addition of $\mathrm{OM}$ to the raised-bed soils, with the exception of rice straw, resulted in priming effect. Therefore, rice straw is recommended for use as a source of OM to increase OM content of the raised-bed soils through the stabilization of OM.

\section{ACKNOWLEGDMENT}

This project was funded by the Ministry of Agriculture, the Republic of Indonesia through the Grant of Partnership Cooperation for Research and Development of National Agriculture(Kerjasama Kemitraan Penelitian dan Pengembangan Pertanian Nasional KKP3N) 2014.

\section{REFERENCES}

Aprianis, Y. 2011. Produksi dan laju dekomposisi serasah Acacia crassicarpa A. Cunn.di PT.Arara Abadi. Tekno Hutan Tanaman 4, 41 - 47.

Baldock, J.A., Masiello, C.A., Gelinas, Y., Hedges, J.I., 2004. Cycling and composition of organic matter in terrestrial and marine ecosystems. Marine Chemistry 92, 39-64.

Blagodatskaya, E., Kuzyakov, Y., 2008. Mechanisms of real and apparent priming effects and their dependence on soil microbial biomass and community structure: critical review. Biology and Fertility of Soils 45, 115-131.

Bremer, J.M. and C.S. Mulvaney. 1982. Nitrogen-total. In: A.L. Page and D.R. Keeney (eds). Methods of Soil Analysis Part 2: Chemical and Biological Methods. Soil Science Society of America Inc., Madison WI, pp. 595-709.

Chesson, A. 1981.Effects of sodium hydroxide on cereal straws in relation to the enhanced degradation of structural polysaccharides by rumen microorganisms. Journal of Science \& Food Agriculture 32, 745-758.

Fontaine, S., G. Bardoux, L. Abbadie, A. Mariotti. 2004. Carbon input to soil may decrease soil carbon content. Ecology Letters 7, 314-320.

Fontaine, S., S. Barot, P. Barre, N. Bdioui, B. Mary, C. Rumpel. 2007. Stability of organic carbon in deep soil layers controlled by fresh carbon supply. Nature 450, 277-U210.

Nelson, D.W. and L.E. Sommers. 1996. Total carbon, organic carbon and organic matter. In: D.L. Sparks (ed). Methods of Soil Analysis Part 3: Chemical Methods. Soil Science Society of America-American Society of Agronomy Inc., Madison WI, pp. 961-1011.

Payne, R. 2008. A Guide to Anova and Design in Genstat. VSN International, Hempstead, UK. 1180 p.

Rasmadi, M. 2003. Perubahan sifat kimia tanah tukungan karena perubahan umur tukungan pada lahan pasang surut. Agroscientiae Vol. 10 No. 1: 43-51. 
Saidy, A.R., R. J. Smernik, J.A. Baldock, K. Kaiser dan J. Sanderman. 2013. The sorption of organic carbon onto differing clay minerals in the presence and absence of hydrous iron oxide. Geoderma 209-210: 15-21.

Saidy, A.R., R. J. Smernik, J.A. Baldock, K. Kaiser, J. Sanderman dan L.M. Macdonald, L.M. 2012. Effects of clay mineralogy and hydrous iron oxides on labile organic carbon stabilisation. Geoderma 173: 104-110.

von Lützow, M., Kögel-Knabner, I., Ekschmitt, K., Matzner, E., Guggenberger, G., Marschner, B., Flessa, H., 2006. Stabilization of organic matter in temperate soils: mechanisms and their relevance under different soil conditions - a review. European Journal of Soil Science 57, 426445.

Yuwono, M. 2008. Dekomposisi dan mineralisasi beberapa macam bahan organik. Jurnal Agronomi 12, 1-8. 